\title{
Student Admission through Hafidz Path Program: A Case Study of an Indonesian University
}

\author{
Agus Machfud Fauzi \\ Universitas Negeri Surabaya \\ Surabaya, Indonesia \\ agusmfauzi@unesa.ac.id
}

\author{
Ayu Mega Diarti \\ Universitas Negeri Surabaya \\ Surabaya, Indonesia \\ ayudiarti16040564025@mhs.unesa.ac.id
}

\author{
Ratih Rohmawati \\ Universitas Negeri Surabaya \\ Surabaya, Indonesia \\ ratihrohmawati16040564009@mhs.unesa.ac.id
}

\begin{abstract}
This study aims to look at educational policies that are beneficial to the nation's generation by realizing the vision and mission or ideals of education. Education has so far only been in the process of teaching humans to understand the academic world and society. UNESA as one of the public universityes provides a new policy for students with special characteristics in the field of Islam. The registration of new students through the hafidz university entrance test has been opened starting in 2018, Universitas Negeri Surabaya (UNESA) sees that they are hafidz, including the next generation of the nation who are needed and deserve to get an equal education. This study uses a qualitative approach with the pre-perspective of the theory of phenomenology Alfred Schutz. The subjects of the study were 2018 new students who were accepted through Hafidz. The results of this study indicate that this program is included as a program that must be developed and maintained because it sees young people memorizing the Qur'an as adolescents with special characters. This kind of policy should be applied to all prospective students who have advantages in developing religion with all religious backgrounds whose existence is recognized in the Republic of Indonesia
\end{abstract}

Keywords- Policy, Higher Education, Hafidz Students , religion

\section{INTRODUCTION}

Policies are actions that affect changes in an institution. According to Hough [2] the word policy is a word that is difficult to understand and has many contexts because it is often used in different and diverse discussions. The process of a policy exists based on public assumptions regarding the values and underlying conflicts. Policies are not just born but policies are born from the context of a special context, pressure, from a specific structure, including born from the elements of culture and community aspirations [5]. One form of policy is the policy in higher education. Educational policy is divided into two namely education policy by the government and internal education policy. The existence of educational policy is certainly born from the ideals or goals of the nation and educational institutions to improve the quality of education.

Education is a development process that prepares and shapes human resources into useful actors for the nation. The educational process can form actors who function in the fields of life, population, politics, economics, employment, and social culture. The role of education in creating a superior, innovative and creative generation out performs the main goals. Therefore, in addition to carrying out policies from the Ministry of Research and Technology, educational institutions are also allowed to determine policies that are in accordance with the conditions and objectives of the agency. The importance of education policy is as a product of decision making in educational institutions that are legal and neutral and adapted to a moderate educational environment. Thus, the assumptions of the public who want an increase in educational institutions can be realized.

Educational policy by educational institutions is awaited state policy. Internal education policy is the consideration of educational policies which form the basis of operationalizing institutionalized education. In accommodating religious young generation, there are currently around 23 tertiary institutions in Indonesia making a new policy in accepting new students. Currently students who have advantages in religious fields such as memorizing the Qur'an are easily facilitated to enter state universities. Higher Education at UNESA, for example, as a public university, implements a new policy in student admission through the hafidz route. This has been released by Ministry of Higher 
Education, Research and Technology (Kemristekdikti) that the university is free to make internal policies in the admission of new students through the memorization of the Qur'an [1].

\section{Policy of Higher Education}

Before talking about higher education policies, it is very important that someone understands the concept of previous policy. Policies are often regarded as rules, even though policies are different from rules and laws. In its scope the policy is divided into two namely public and privacy policies. Public policies are usually made by the government and privacy policies are made by private or private bodies. In the world of higher education there are government policies as well as policies from Kemristekdikti. In addition, education is allowed to make privacy policies in the institution as long as it does not deviate from the main objectives of education and is approved by the government [8].

Higher education or higher education is the final level of education that is desired by students. Although in practice not all humans are able to take higher education. The existence of a tertiary education system has been stipulated in Law Number 20 of 2003 concerning the education system chapter VI section three of article 19 concerning pathways, levels, and types of education that a tertiary institution is a level of education after secondary education which includes several educational programs namely: diploma, bachelor, master, specialist, and doctoral degree. Higher education is held openly for anyone. Higher education is available in several forms, namely academies, polytechnics, high schools, institutions or universities. In higher education there are three levels of tertiary education, namely education, research, and community service.

Some opinions expressed about the concept of public policy, public policy is always synonymous with government policy. Where whatever is done or decided by the government has certain goals and objectives, in this case it means the government is free in determining policies. However, in this authority the government has anticipated the impacts and consequences that arise in the future, before agreeing on a policy. Policy does not merely emerge, but policies emerge from conflict and public assumptions. In higher education there are several compulsory components, including consisting of institutions, study programs, accreditation, lecturer qualifications and so on [9].

Higher education policy will continue to be developed to prepare generations who are ready for globalization since the MEA in 2016, this is done to improve the competence of the Indonesian people to compete with the world community that is based on knowledge (knowledge based society). According to minister of Kemristekdikti, education must be able to produce two important things to face the world. The first is to create character and creative people based on the mastery of science. The second is able to innovate with technology to create the industrial world in the form of employment opportunities to support the welfare of the people. These two things are quite clear as the race of tertiary institutions to create superior and superior generation. The autonomous policy of the institution is permitted by the Menristekdikti which aims at this. One of the busy policies at this time and began to be implemented by institute colleges or universities is the acceptance of new students through the path of memorizing the Koran. The policy is absolutely not prohibited by Menristekdikti, instead they support and get legalization in 2019 [3].

\section{Admission Pathway}

According to the Law of the Republic of Indonesia Number 22 Article 01 of 1961 concerning tertiary institutions, it is explained that tertiary institutions are scientific institutions that have the task of conducting education and teaching above secondary level tertiary institutions, and which provide education and teaching based on Indonesian national culture and by means of the scientific one (Undang- Undang). Higher education institutions as providers of education after upper secondary education, who are ready to accept prospective students with a variety of pathways that are set. That way, each of these tertiary institutions has a policy system to determine the registration path for prospective new students. The policy system is made for prospective new students who are obtained from high school (SMA) graduates and the like. The selection to enter tertiary education varies in the application of the system, especially at state universities. There are three stages of admission at UNESA, namely, the first step is through the National Entrance to State Higher Education (SNMPTN) pathway or commonly referred to as the invitation pathway, the second is through the Joint State Entrance Entrance Selection (SBMPTN) and the last is the entry stage through the New Student Admission Selection (SPMB).

The SNMPTN pathway has been held since 2013, the application of which is based on report cards and other achievements. This pathway applies the principle of fair, accountable, transparent, and also non-discriminatory which distinguishes between sex, religion, ethnicity, race, social position, and level of ability in the economy. The SBMPTN pathway is carried out through the 2012 written examination path, which uses a national selection pattern based on written test results or also skills tests. While for the last track, the SPMB is "New Student Admission Selection" or can be referred to as a selection through an independent pathway, in this SPMB is divided into 4 types namely SPMB Bachelor of Achievement, SPMB Regular Bachelor, SPMB Regular Diploma and also SPMB Bachelor Hafidz. Especially for the Regular Undergraduate Program SPMB for prospective applicants in the field of Sports or in the Faculty of Sports with S1 Sport Coaching Education Study Program only.For the SPMB pathway program at UNESA, in the previous year there were only 3 types, but in 2018 UNESA is ready to launch a new program through the SPMB pathway named SPMB Undergraduate Hafidz [7].

SPMB Bachelor of Hafidz or the Qur'an Recitation Path is the first time it was opened at UNESA in 2018. The first time it opened, UNESA had received as many as 18 prospective students memorizing the Qur'an. The aim is to establish or 
open the Hafidz pathway at the University with this general or non-religious shutter, it is hoped that in the future UNESA will be able to create special student seeds in the religious field specifically to continue representation in the Musabaqah Tilawati Qur'an (MTQ) festival, so that although it can be said public university, but UNESA is also able to compete in the religious field well.This SPMB Bachelor Hafidz is indeed a breakthrough that has just been carried by UNESA, so that many support the running of this program well, especially those mandated as examiners of memorizing the Qur'an. This pathway is also capable of being a religious symbol and honing the strengths of Indonesian hafidz to get the same education, because that does not mean those who memorize the Qur'an are of low academic ability, instead prospective students who have memorized the Qur'an are not need to be tested again their academic abilities, because they have also once been like other prospective students, so there cannot be underestimated about their academic abilities [10].

Al-Qur'an memorization path is carried out with a minimum requirement to memorize the Qur'an, 15 Juz with the criteria for the provisions of tahfidz, tajwid, and qira'ah. The requirements to attend and enter this state university have been determined and planned carefully and without a written test on academics, so only 3 of these assessment criteria can be used to enter the University.

\section{General University Opening Hafidz Path "Memorizers of the Qur'an"}

The path of memorizing the Qur'an or Hafidz to enter tertiary institutions is mostly carried out by tertiary institutions in an Islamic nuance. But lately, the Qur'an memorization path is also applied by public universities with the aim of providing opportunities for prospective new students to be able to continue their education by honing the strengths of Indonesian hafidz to get the same education. For this reason, public universities are also able to compete with Islamic-nuanced universities in accepting prospective new students by memorizing the Qur'an. From several public universities opening the hafidz memorization path of the Qur'an has different evaluation criteria. Each criterion is agreed upon and adjusted to the capabilities of the University.

\section{Hafidz Pathway Program Policies at UNESA}

The hafidz pathway program is a selection program for new student admissions at UNESA. The program has just begun in 2018, the program selection process with an oral test of memorization of the Koran owned by the registrant with the provisions of having a memorization of at least 15 juz. The program does not merely appear as a formality, but it is expected that in the future the UNESA will have excellent students in the religious field. By having the assets of students proficient in religious fields will later be used as representatives in the Musabawah Tilawatil Quran festival (MTQ) to the national level.

Admission of new students to the hafidz path began to be sought after by those who were proficient in the field of religion. If in the decentralization of education management from the center to the regions there are stages that must be passed in order for a policy to be implemented. These stages include resistance to socialization, resistance to piloting (a trial phase acceptable to the public), and the dissemination stage [6]. Likewise the hafidz pathway program at UNESA with stages. Stages of publication are the main and are also accompanied by stages of socialization both through print writing and the media on the UNESA website. Then the implementation stage is the hafidz track level test with oral test and several religious lecturers as a test of the fluency of memorizing memory. After that the coaching stage, but this stage has not yet run. Information from students who have passed and are accepted as students of UNESA will later be a kind of coaching fund in the form of a monthly allowance to be given to hafidz students. This is as a facility and privilege given to hafidz students.

\section{The "Alfred Scutz" Phenomenology Theory}

Phenomenology according to "Alfred Scutz" primarily examines the "intersubjectivity" which means all motives, actions, desires, meanings, and understanding in depth by means of understanding life-world and can also understand everyday life. With the intention that reality is doubly fat, namely there is an empirical objective world and aworld of subjective awareness that is directly about human experience related to an object. So this phenomenology is used to help in understanding social phenomena that occur directly in society [4].

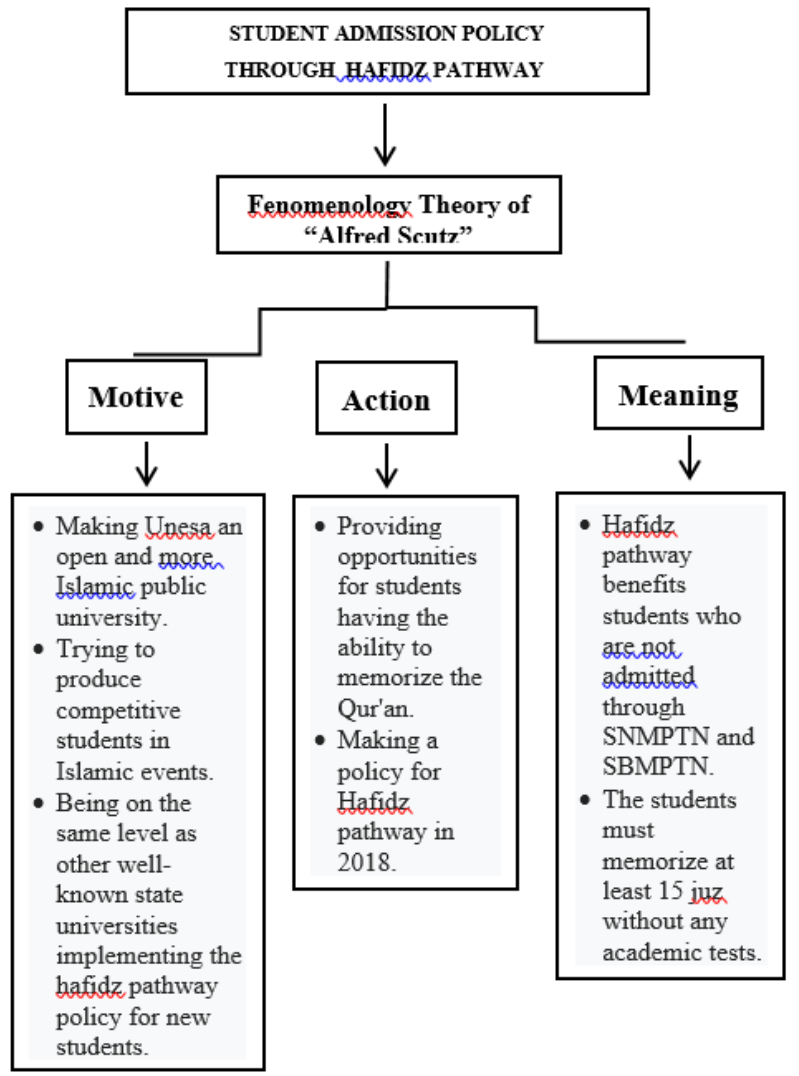

Fig 1. Hafidz Pathway Policy Based on Alfred Scutz's Theory 


\section{Education Policy Critics}

A policy comes from several stages and frameworks in developing a policy so that it is accepted by the community and people related to the policy. The policy framework consists of information, methods of obtaining information, forms of policy analysis and policy arguments. One thing that needs to be highlighted is the policy argument because policy exists concerning how much benefit can be given to convince the public. Policy has arguments so that policy criticism can occur, namely: (1) information related to policies, (2) conclusions from policy arguments, (3) justification with various things such as intuitive, analytical, authoritative, programmatic or assessment , and based on cause and effect, (4) supporters, namely things done to strengthen the justification through scientific formulas, proposals on expert fields, and moral principles, (5) evidence, a policy critique is certainly based on evidence in the form of conclusions from various sources used in the assumption of the second argument, (6) the criterion, is a prerequisite at the level of analysis of the argument in beliefs about policy claims [6].

The education policy in hafidz pathway students is currently being discussed and is even becoming a large program implemented state universities in Indonesia. UNESA as one of the state universities that implemented the policy starting in 2018, many UNESA students themselves do not even know the policy but some do. One of the students who knew the policy was a student from mechanical engineering major Ahmad Baidowi, he argued that the policy could have caused SARA conflict. As a student who is active in one of the Islamic religious organizations agreed and disagreed with the policy, agreed if applied according to Islamic nuances. While disagreeing if Hafidz students are easily facilitated through Hafidz, it should also be felt by students who memorize the Bible or the Bible.

It needs to be questioned actually about the benefits of the policy, because at UNESA as a public university, there is only one major in the field of religion, namely Islamic economics. Not disrespecting students who are able to memorize the Qur'an but the policy can have a negative impact on the students themselves. Instead of deepening the knowledge tested in the general university entrance examination students may instead choose to multiply their memorization. Even though when they enter the rote it doesn't help them become proficient in the majors they take. Besides this policy should not only be specifically for students who are Muslim but also non-Muslims who have expertise according to their religion. If we still apply the fifth precepts of Pancasila precepts 'Justice for All Indonesian People' then those who are non- slam religious people are entitled to a similar policy. As explained by one of the UNESA students who took part in arguing about this program, this is one of the UNESA students who are non-Muslim, saying that "since the implementation of the policy regarding SPMB Bachelor Hafidz 2018 is no problem for him if UNESA applies the policy, but seeing again that UNESA is a public university then from that note that UNESA must also plan to provide a pathway for accepting prospective new students to non-Muslim religions too, because it is also natural that UNESA applies the hafidz path because most registrants are Muslim, if UNESA also adopts plan the path to accepting prospective new students for non-Muslims is what makes it fair ". Therefore, this kind of policy can lead to discrimination against minority religious communities while they include residents of Indonesian citizens.

It is unfortunate that many people are still not aware of this. Even though they know that Indonesia is a diverse country, diverse in race, culture, language, to religion. The policy has been applied to 23 universities, maybe if the policy is applied to private universities it is not so much an issue because the cost of education is not sourced from the state. State universities receive quite a lot of tuition fees from the government. Everyone should have the right to get a fee from the government because Indonesia is not an Islamic state but a country with a variety of religions. The policy is good, but it would be nice if a policy can be enjoyed by all the existing communities without specializing in one group, especially the majority.

Policies for new students based on the goodness of religious groups have developed. In 2019 UNESA provided facilities for the admission of new students with hafidz and religious excellence, for example Christians and Catholics felt the policy.

\section{CONCLUSION}

The new education policy made by Unesa is the policy of admitting Hafidz SMPB students which was formalized in 2018. The path is of interest to students who have special abilities in the field of religion, namely memorizing the Koran. With this path they can enter UNESA using other than the SNMPTN and SBMPTN pathways. If they have been accepted at the village they will be given other facilities specifically or such as coaching money. This new path was followed by 18 participants and all of them were declared to have passed the tests that had been held. Participants who follow this path are exempt from academic written tests, only through oral tests according to the provisions they are declared to have passed. Education policy must be felt by all humans, not in favor of anyone. The policy must not forget the principle of justice for all its citizens.

\section{REFERENCES}

[1] Antara, Menristekdikti Membebaskan Terima Mahasiswa Baru Lewat Penghafal Al-Qur'an. Tribunnews. 2017.

[2] Hough, 1994.

[3] Kemenristekdikti, "Kebijakan Pengembangan Pendidikan Tinggi," 2015. [Online]. Available: https://www.ristekdikti.go.id/ pengumuman/open-53/. [Accessed: 11-Feb-2018].

[4] Nindito, "Fenomenologi Alfred Scutz: Studi tentang Konstruksi Makna dan Realitas dalam Ilmu Sosial,” J. Ilmu Komun., pp. 7994, 2005.

[5] Saludi, R, “Makalah Pengertian dan Fungsi Kebijakan,” 2015 [Online]. Available: https://riyan.blogspot.com/2015/09/makalahpengertian-dan-fungsi-kebijakan.html. [Accessed: 11-Feb-2018].

[6] Sa'ud, Pengembangan Kebijakan Pendidikan dalam Kerangka Otonomi Daerah. 2015. 
[7] SIPENMARU, “SIPENMARU UNESA.” [Online]. Available: https://sipenmaru.unesa.ac.id/ [Accessed: 12-Mar-2018]

[8] Sutapa, M, Kebijakan Pendidikan dalam Perspektif Kebijakan Publik., pp. 13, 2008.
[9] UNESA, "UNESA Buka Jalur Prestasi Bagi Para Hafizh." [Online]. Available: https://www.unesa.ac.id/unesa-buka-jalurprestasi-bagi-para-hafizh. [Accessed: 12-Mar-2018]. 